Dialectologia 19 (2017), 23-40.

ISSN: 2013-2247

Received 8 July 2015.

Accepted 12 October 2015.

\title{
NEW YORUBA IDIOMS AND IDIOMATIC EXPRESSIONS: \\ A NEW MODE OF EXPRESSION IN POLITICAL ARENA
}

\author{
Dayo AKANMU \\ Adeniran Ogunsanya College of Education* \\ dayoakanmu2002@yahoo.com
}

\begin{abstract}
New idioms and idiomatic expressions, which are modern stock expressions, constitute communicative clogs in Yorùbá routine discourses because of their semantic complexity and deviant nature. Existing studies have established their scope of usage in Yorùbá music but have hardly addressed their communicative adaptability in politics. This paper investigated issues expressed with these idioms, context and strategies for using them in political arena. This is with a view to establishing their communicative and stylistic relevance in Yorùbá discourses. The paper adopted Mukarovsky's theory of Standard Language because of its capacity to explain the "differentia specifica" between the language of everyday interaction and literary language. Data were collected from different routine communicative discourses of politicians and party members on radio, during political rallies or campaigns and were subjected to pragmatic and stylistic analysis. Political issues were expressed using new idioms and idiomatic expressions in the following sociopolitical contexts: Eté for corruption/stealing; Ojúyọọ́ for under achiever; Yóó wọlé ẹẹken si for deceit; Ó bọjẹe tì for collective support; Oyin ni o for a successful tenure; Ajímọ̀bi for collective responsibility; Nàijá for affection/disappointment and Kárí go/Kárí kọ̣mù for continuity and discontinuity. Nominalisation, Pidginisation and dialect expressions were the strategies employed for the formation of new idioms in this paper. These strategies were used to express different political happenings contextualized in underachievement, sloganeering for support, deceit, and acceptance/rejection for second term in office respectively. New idioms and idiomatic expressions, used
\end{abstract}

\footnotetext{
* School of Languages. Adeniran Ogunsanya College of Education. Otto/ljanikin P.M.B 007, Festac Town -
} Lagos, Nigeria. 
to express sociopolitical issues in Yorùbá routine communication, occurred in mediated and nonmediated contexts and were conveyed through nominalization, pidginisation, and dialect expressions. These idioms reflect dynamism and modernity-constrained stylistic choices in Yorùbá.

\section{Keywords}

new idioms, Yorùbá, strategies, politics, stylistics

\section{NUEVOS MODISMOS Y EXPRESIONES IDIOMÁTICAS EN YORUBA: UN NUEVO MODO DE EXPRESIÓN EN POLÍTICA}

\section{Resumen}

Los nuevos modismos y expresiones idiomáticas, que son expresiones comunes modernas, constituyen obstrucciones comunicativas en los discursos rutinarios en yoruba debido a su complejidad semántica y naturaleza desviada. Los estudios existentes han establecido su uso en la música en yoruba, pero apenas han abordado su adaptabilidad comunicativa en la política. Este trabajo investiga las expresiones usadas con estos modismos, y el contexto y las estrategias para utilizarlos en el ámbito político. El fin es establecer su relevancia comunicativa y estilística en los discursos en yoruba. El artículo adopta la teoría de la lengua estándar de Mukarovsky debido a su capacidad para explicar la "especificidad diferencial" entre el lenguaje de la interacción cotidiana y el lenguaje literario. Los datos fueron extraídos de diferentes discursos comunicativos rutinarios de políticos y miembros del partido en la radio, durante campañas políticas, y fueron sometidos a análisis pragmático y estilístico. Los temas políticas se expresaron utilizando nuevos modismos y expresiones idiomáticas en los siguientes contextos sociopolíticos: Eté para corrupción/robo; Ojúyọbọ para inexperto; Yóó wọlé ẹẹken si para el engaño; Ó bojẹ tì para el apoyo colectivo; Oyin ni o para un mandato exitoso; Ajímọbi para la responsabilidad colectiva; Nàijá para afecto/decepción y Kárí go/Kárí kọọmù para continuidad y discontinuidad. Expresiones nominalizadas, dialectales y pidgin fueron las estrategias empleadas para la formación de nuevos modismos. Estas estrategias se utilizaron para expresar diferentes acontecimientos políticos contextualizados en el fracaso, consignas para el apoyo, el engaño y la aceptación/rechazo en el segundo mandato en el cargo, respectivamente. Los nuevos modismos y expresiones idiomáticas, utilizados para expresar temas sociopolíticos en la comunicación rutinaria en yoruba, se daban en contextos mediados y no mediados y se transmitían a través de la nominalización, la pidginización y las expresiones dialectales. Estos modismos reflejan el dinamismo y las opciones estilísticas constreñidas por la modernidad en yoruba.

\section{Palabras clave}

nuevos modismos, yoruba, estrategias, política, estilística 


\section{Introduction}

This paper was motivated by the saying 'the world is a global village' which imposes new global communicative challenges on the Yorùbá people especially the politicians and their followers. The evolution of new idioms and idiomatic expressions thus becomes a coping strategy to meet the new communicative challenges. Globalisation is a phenomenon that filters into all domain of human experience, especially politics. As a result of this, the Yorùbá, politicians like any other politicians in the Third World countries, are faced with the challenges of how to express their ideas and experiences emanating from globalization. These politicians have a duty to inform, enlighten and educate their people about the latest development brought about by the wind of change blowing across the globe. At a time that Nigeria is trying to develop and sustain a democratic system of government, the Yoruba politicians cannot afford to be aloof to this global development. The politicians must be in the forefront of the urgent need to educate Nigerians about new developments in politics. In doing this, they are incapacitated with certain linguistic constraints imposed on them by their language such as the unavailability of words in their language and difficulties in getting appropriate lexical expressions for their ideas. To overcome this, the choice left for politicians according to Babalọlá (1972), Awóbùlúyì (1992: 26) and Olateju (2005) is to coin new words or idioms and also to attach new meanings to the existing ones. In this paper, such new coinages, words and expressions are hereby referred to as 'new idioms or expressions'.

By and large, in this paper, attempt was made to address political issues expressed with new idioms and idiomatic expressions in Yorùbá and strategies for using them with a view to establishing their communicative and stylistic potential in Yorùbá discourses.

\section{New idioms and idiomatic expressions}

New idioms and idiomatic expressions are quintessentially modern stock expressions, formed in response to the needs of the moment arising as a result of the 
linguistic constraints of the users which consequently necessitates creation of new words and expressions. They are so called not only because of their complexity which requires the overlapping tendencies of their semantic realizations, but also because of their distinctive difference from old, traditional idioms. As a matter of fact, they straddle metaphor and euphemism and also serve as replication of the established Yorùbá idioms both in form and meaning. They are in spoken and written forms and mainly operate at the lexical and phrasal levels. They are also multi-functional because of their semantic unity. They may equally function as nouns, verbs and adjectives. New idioms and idiomatic expressions are created either through coining, (creating and recreating of new words and expressions) or by investing old words and expressions with new meanings. New idioms are creative, new, strange and fresh by nature. They are not vague expressions and their origins are also known to the users who are always dazzled whenever they come across them in any context.

\section{Existing studies on new idioms}

Few scholars have turned their attention on the study of new idioms and idiomatic expressions in Yoruba. These scholars include Àkànmú (2003) and Ọlátẹjú (2005). Some scholars have described idioms as terms referring to words whose meanings cannot be predicted from the individual elements in them (Babalọlá 1972; Bámgbósé 1975; Owólabí 1976; Awóbùlúyì 1992; and Yusuf 2002). These studies have not directly dealt with some issues raised in this paper but they serve as the springboard for this paper.

While discussing idioms and coinages, Babalolá (1972) states that neologism is used for expressing new items and ideas brought into Yorùbá culture by foreigners. His view bears direct relevance to this study in that, neologism is one of the linguistic strategies employed in the formation of new idioms.

Bámgbósé (1975) identifies vocabulary-coining strategies to include nominalization, explication, semantic extension, and loan words, among others. Through this, the Yorùbá lexicon is being expanded. Àkànmú's (2003) is not specifically on new idioms but it has some semblance of new idioms in the discussion and examples 
cited. He employed a sociolinguistic analytical method for the interpretation of the work which he referred to as coded language used by certain groups of the Yorùbá society. He cites numerous examples of such expressions that are used in different contexts and discusses their functions in daily activities of the users, even though many of the examples cited as slang are not slang but new idioms used by a considerable number of people.

Ọlátẹjú's (2005) work is a remarkable contribution on new idioms, their formation and interpretation. He examines new idioms and idiomatic expressions from both the linguistic and literary points of view. He adopted Chomskyan Transformational Generative Grammar (TGG) while stylistic and some sociolinguistic variables were used to bring out aesthetic and communicative potential of the new idioms and idiomatic expressions.

\section{Methodological approach}

Data were collected from different routine communicative discourses of some prominent Yorùbá politicians and parties' members on radio, during political rallies, campaigns, sloganeering in Lagos, Ìbàdàn and Òșogbo. These three cities were chosen because of their urbanized nature and the constant usage of new idioms and idiomatic expressions by the politicians. Data were subjected to pragmatic and stylistic analysis.

\section{Standard language vs literary language}

The theory of Standard Language was formulated in 1970 by Jan Mukarousky to solve the problem of relationship between Standard Language (SL) and Literary Language (LL). The suitability of this model lies in the fact that it can be used to explain the differentia specifica between the language of ordinary usage and literary expressions as well as using it to explain and interpret the deviant and inventive nature of new idioms and idiomatic expressions. 
According to Mukarovsky (1970), Standard Language (SL) is the language of everyday conversation. Its purpose is the understanding between the speaker and the audience with the aim of enhancing effective communication (Crystal 1997: 68). Language of ordinary discourse is casual and devoid of ornamentation. It is unexamined and uncritical. It does not draw attention to itself or open up provocative questions to the nature of its coding. It is often used in schools, on radio, during political campaigns and preaching. Its priority is effective communication which calls for employment of words and phrases that can be fully comprehended. Therefore, to enhance undistorted communication in Standard Language (SL), language must conform to the entire linguistic norms. Concepts crucial to the Standard Language are 'backgroundig' and automatization illustrated by the example below:

\section{Làkàsọ́rọ Literal meaning: corrupt coinage from La casera drink Idiomatic: No story/end of discussion}

The above expression is a phonological creation from the name of a particular non-alcoholic drink in circulation all over the country. The expression 'làkàsẹrà (La casera) is the standard form that has been foregrounded or de-automatized as 'làkàsórọ̣'. In other words, làkàsọrọ̣ is the artistic form of La casera. There is no expression like 'làkàsọ́rọ̣' in the standard language. 'Làkàsẹrà' is automatized and serves as the background from which 'làkàsọ́rọ̆' is created and used as an idiom. 'Làkàsọ́rọ̆' which can be interpreted as 'no story/end of discussion' is made new, thereby becoming element of surprise because it has violated the Yorùbá lexical formation rules.

Although, foregrounding is logically prohibited in Standard Language, this is not to say that it is not visible in Standard Language as Mukarovsky indicates its possibility in journalistic language where it can be used as subordinate to communication in order to draw the readers' attention more closely to the issue at hand or the item of information articulated. This must have justified the use of new idioms and idiomatic expressions in political routine communicative situation discussed in this paper. 


\section{Linguistic strategies for the formation of new idioms}

According to Bámgbósé (1975), word formation is a universal linguistic concept that is concerned with the study of the patterns on which a language forms new lexical item. As far as formation of new idioms and idiomatic expressions are concerned in this paper, the linguistic strategies involved in their formation include the following:

i) Nominalisation

Nominalisation is universally known as one of the veritable tools for generating new words in virtually every language. Ruwet (1973: 172) views it as the derivation of a noun phrase from an underlying clause or sentence; or the process of forming a noun from other word classes. Below are some examples of new idioms and idiomatic expressions created from the linguistic process of nominalization.

\begin{tabular}{|l|l|l|}
\hline \multicolumn{1}{|c|}{ Idioms } & \multicolumn{1}{|c|}{ Literal meaning } & \multicolumn{1}{c|}{ Idiomatic meaning } \\
\hline $\begin{array}{l}\text { oní + àsà + kí + àșà } \\
\text { (owner-of-bad-culture) }\end{array}$ & $\begin{array}{l}\text { aláșàkașà } \\
\text { (owner of bad culture) }\end{array}$ & $\begin{array}{l}\text { Onísọkúsọ } \\
\text { (vulgar person /user of } \\
\text { nonsensical language) }\end{array}$ \\
\hline $\begin{array}{l}\text { oní + ebòlò } \\
\text { (owner-of-ebòlò) }\end{array}$ & $\begin{array}{l}\text { Elébòlò } \\
\text { (seller of ebòlò vegetable) }\end{array}$ & A prostitute \\
\hline $\begin{array}{l}\text { má + fo + gọ́tà } \\
\text { (do-not-jump-over-the gutter) }\end{array}$ & mini skirt & indecent dressing \\
\hline
\end{tabular}

ii) Pidginisation

According to Nichols (1980), pidgin is a contact language which is an amalgam of linguistic elements of two or more languages and which arises in social and economic transactions between, at least two groups speaking different languages by a process of restriction and simplification of one of the languages of these groups, usually that is in a socially superior position. This process of restriction and simplification is termed Pidginisation. By definition, a pidgin is no one's native language. In the process of becoming notarized, the pidgin undergoes extension and elaboration and thus becomes creolized. 
Pidginisation, as used in this paper, is a strategy for loaning words or expressions that are not only pidginized but also foregrounded with idiomatic undertones for communicative purposes, especially by the youths and non-fluent speakers of the language. Examples of such idioms and idiomatic expressions include:

\begin{tabular}{|c|c|c|}
\hline Idioms & Literal meaning & Idiomatic meaning \\
\hline $\begin{array}{l}\mathrm{Vb}+\mathrm{Vb} \text { or } \mathrm{V}_{1}+\mathrm{V}_{1} \\
\text { Kárí kọọmù }- \text { kárí + kọọmù = } \\
\text { carry come }\end{array}$ & Carry and come & $\begin{array}{l}\text { Loan form of the pidgin English } \\
\text { word 'carry come' for: come } \\
\text { in/pack. }\end{array}$ \\
\hline Kari go - kari + go = carry go & Carry go & $\begin{array}{l}\text { Loaned form of the pidgin English } \\
\text { word 'carry go' for: move on/ride } \\
\text { on/go away }\end{array}$ \\
\hline \multicolumn{3}{|l|}{$\mathrm{Vb}+$ Noun } \\
\hline $\begin{array}{l}\text { Kari moni - kari + moni = carry } \\
\text { money }\end{array}$ & Put money on the head & $\begin{array}{l}\text { Loaned form of the English word } \\
\text { 'carry money' for: carry } \\
\text { passengers. }\end{array}$ \\
\hline
\end{tabular}

\section{iii) Dialect Expression}

Dialect, according to Salami (2006), is a distinct form or variety of a language that is associated with a recognizable regional, social or ethnic groups different from other forms of the language by specific linguistic features such as pronunciation, grammar or vocabulary, especially a variety of speech differing from the standard language or speech pattern of the culture in which it exists. As far as the new idiom is concerned, dialect expression is seen as a dialect variant of word present in the standard language and sometimes used consciously for entertainment. Examples of where dialect are used as idioms and idiomatic expressions include:

\begin{tabular}{|l|l|l|}
\hline \multicolumn{1}{|c|}{ Idioms } & \multicolumn{1}{|c|}{ Literal meaning } & \multicolumn{1}{c|}{ Idiomatic meaning } \\
\hline $\begin{array}{l}\text { E e ti i ri nnken ken } \\
\text { (you have not seen } \\
\text { anything). }\end{array}$ & You have only seen little. & $\begin{array}{l}\text { Greater show awaits you/that } \\
\text { is just a tip of the iceberg. }\end{array}$ \\
\hline
\end{tabular}

The underlined word in the above excerpt is borrowed from the Oke-Ogun dialect of Yoruba. In standard Yoruba, the word should have appeared thus: 


\section{E e ti i ri nnkan kan}

(You have not seen anything)

The above expression rendered in Ibarapa dialect is often found in the adverts, addresses and speeches of politicians or even, in music of some artistes and it often has a stylistic significance of comic effect or entertainment.

\section{Analysis of new Yoruba idioms and idiomatic expressions used in sociopolitical} context

This section is devoted to analyzing and interpreting idioms and idiomatic expressions found in the data collected for this paper. This analysis is to provide insight into communicative and stylistic relevance of the new idioms. Because of the possibility of new idioms and idiomatic expressions possessing many interpretations and the fact that meaning cannot be determined by their individual lexical constituents, this phenomenon is better studied and analyzed from pragmatic and stylistic perspectives with a view to determined their communicative potential in political discourses.

(i) - Eté literal meaning: Yorubanized version of the name Etteh Idiomatic: thief/looter

The context in which the name emerged is a context of corruption involving a former Speaker of the Nigerian House of Representatives. The expression 'Eté' as a new idiom is commonly used today by people, especially in the present political dispensation in Nigeria. It is a corrupt coinage of the name Etteh. Eté is metaphorically used to refer to 'a thief or a looter of public treasury' like the former speaker of the Nigerian House of Representatives who was allegedly accused of corruption and forced to resign on October 31, 2008 over the crisis that emanated from the N628 million building renovation scandal in 2007 before she was discharged and acquitted in a court of law. 
(ii) - 'Ojúyọbộ' Literal meaning: bulging eyes

Idiomatic: physical description of an under-achiever

The above is one of the new idioms used to express 'abuse'. The expression which literally means 'bulging eyes' is contextualized in one of the political statements credited to a prominent politician and a one time gubernatorial candidate in Lagos State. In attempt to run down the ruling party in one of his political campaigns in Yaba, he remarks:

\author{
...Ará Èkó kii șe Babiháalà \\ E sọ fún àwọn ojúyọbợ kí wợn kó jígí wọn lọ sí òkè lọ́hùn ún. \\ (Ray Power, March 2007) \\ ...Lagosians are not beggars \\ Tell the Ojúyọbọ́s to carry their eye glasses to the North.
}

Apparently, The politician's good performance as governor during his first tenure was not recognised by his political opponents. Therefore the opponents employed derogatory terms (idioms) to run him down during electioneering campaigns so that they could have an upper hand. The use of this idiom as shown in the above political context makes interpretation easier especially for people who are already familiar with the political issues around which the context revolved. The name 'ojúyọọ' is derived from his physical appearance. This politician is endowed with big eyeballs. But suddenly because of some challenges he had during his tenure as governor which many of his supporters blamed on non-release of the local governments allocation funds by the Federal Government, the endowment later turned to the object of ridicule. Since then, the name ojúyọbọ has been used as an expression to abuse one's enemy or a political opponent

(iii) - 'Yó wọlê ẹẹkện si' Literal meaning: He would win once again Idiomatic: Deceitful comment (for: never again) 
In the above, the expression yó wọlé ẹẹkẹn si which literally means he would emerge the winner once again; is from a specially waxed record for political advert few years ago for a prominent politician who was bidding for a second term as governor of a State in the south-western Nigeria bỳ lyá Aládùkẹ́, a Dadakúàdà exponent. The song pervaded all the radio and television stations in the south-western part of the country. Since it was generally believed that this politician did not do well enough to get a ticket for the second term by his opponents, the song was scornfully imitated by many people. It was very easy for people to imitate and comprehend not only because of its usage in such a familiar political context, but also because of the dialectal variation 'ẹẹkẹn' that was skilfully employed to create a subtle humour in the song. The expression ẹẹkẹn is from Òkè Ògùn dialect which comprises Șakí, Ìsẹ́yìn, Baba ọdẹ, Șẹ̀pẹtẹ̀rí and some parts of Kwara State, especially Ìlọrin, where Ìyá Aládùkẹ hails from. The standard form of ẹẹkẹn is ẹẹkan (once again/more). It is used contemptuously by the opposition party to mean 'he will never win again'. Apart from its idiomatic connotation, it also has humorous and entertainment effects.

(iv) - 'Ó bọjẹ́ ti' Literal meaning: It would never retrogress or go backward Idiomatic: Positive assertion/sloganeering for support, collective action for good governance/ project

The expression 'ó bọjẹe ti', literally interpreted as 'it would not retrogress or go backward' is a refrain to the political sloganeering of a political party in the southwestern part of Nigeria. The governor of a particular State in Nigeria is fond of saying 'Èkó ò ní bàjẹ o' (Lagos will not be backward/destroyed) the response or refrain of which is 'ó bọjẹ $t i^{\prime 2}$ (it would not retrogress or go backward). The governor uses the expression which has become a household idiom in the State, to solicit the support of the people, for the various developmental programmes of his government. In some other States, there are similar political expressions or slogans which have become idiomatic expressions that are meant to sensitise people to the activities of government. In one of these States, during the tenure of the former governor, the sloganeering idiom was 'Oyin ni o': 


\section{(v) - Oyin ni o' Literal meaning: It is honey/shortened of name of Oyinlọlá Idiomatic: Successful tenure}

The expression Oyin ni $o$, is used not only as an appellation, but also as a slogan during the political campaign of a politician whose name and tenure are expected to be as sweet as honey. This politician's tenure as governor was metaphorically predicated as oyin (honey) during an election in his State compared to the hardship experienced by the people of the State under the immediate past governor, whose tenure was characterized by mass retrenchment of teachers. As a metaphor, the expression oyin ni $o$ (it is honey) means someone whose name and tenure are expected to be as sweet as honey. The expression is used to hail the former Governor of a particular State in Nigeria, who always got excited and entertained on hearing oyin ni $o$. This attribute is interpreted based on the socio-political context and in the socio-political views of some people in that particular State as sweet tenure, soothing tenure or a tenure that brings succour. In other words, the context of its usage always provides information which enables people to give the expression an interpretation of a peaceful and prosperous tenure. In another State today, the sloganeering expression is:

\section{(vi) - Àjùmọ̣se Literal meaning: collective implementation Idiomatic meaning: governance is a collective responsibility}

The above is a slogan-turned idiomatic expression used virtually in every home and public place thus:

\section{'k'ợọ̣ọ́lè dáa àjùmọṣe gbogbo wa ni o!}

(for Oyo to be peaceful and prosperous it is our collective responsibilities)

The word 'Àjùmọșe' in the sloganeering idiom is derived from the governor's name 'Ajímọbi meaning 'together we woke up to know the manner of birth' The idiom, Àjùmọṣe (that-which-is-executed-collectively) shares the same derivational strategy with the first three syllable (A/jí/mọ) in the name Ajímọbi (a person we woke up together to experience his birth) with another connotative meaning of 'collective effort' derived 
from the first syllable and vowel $(A)$ in the two names, a first person plural pronoun which eventually expresses 'collective responsibility'. Today, whether on the television or radio, every advert placed by the Oyo State government is ended with k'ợọọ́ lè dáa àjùmọṣe gbogbo wa ni o!' (for Oyo to be peaceful and prosperous, it is our collective responsibilities). The sloganeering has equally become a household expression with the meaning of 'collective responsibility'; even governance is said to be collective responsibility.

(vii) - Nàijá Literal meaning: Yorubanized and shortened of the name Nigeria Idiomatic: Affectionate way of addressing the country Nigeria exclamatory words of disappointment when something strange happens in the polity.

The expression 'Nàijá' is also a new idiom that is frequently used by many Nigerians, especially for entertainment purposes It has become a way of affectionately referring to the country, Nigeria and Nigerians, especially those abroad. Expression like îgbàwo lò ń lọ Nàijá?' (when are you going to Nàijá?) 'șé o ti gbọ láti Nàijá? (have you heard from Nàijá?), 'Nàijá lodư' (Nàijá is the real thing) are common expressions among Nigerians, especially during a football match between Nigeria and any other country. Whenever it is used in contexts such as the foregoing, it facilitates information or background that connotes 'an expression of unity' among Nigerians as far as the meaning is concerned. There are also Nigerian musicians, actors, actresses, comedians and youths who have chosen Nàijá as their affectionate way to address their country and sometimes to express exclamatory words of disappointment. When something crazy happens in the polity, people always exclaim Háà, Nàijá! Nàijá is a created word pronounced in Yorùbá or Pidgin English. It is a name given to Nigeria by Nigerians. It has resonated very well with the educated, semi-educated and the illiterates.

(viii) - Kárí go/Kárí kọ̣mù Literal meaning: Go away/move away Idiomatic: Continue/you are not wanted 
These are new idioms loaned from English. The original English words were correctly used in their Yorùbá form 'kárí go' and 'kárí kọọmù' under different political contexts to connote different meanings. For instance, during the 2003 gubernatorial election in Nigeria the association of market women in a particular State told the former governor of the State in one of his political rallies to kárí go. That is, his candidature is accepted by the people, therefore, he should continue with his ambition to contest as they (the electorate) are solidly behind him. The same year, in another political campaigns/rallies in one of the strongholds of his opponent, he was asked to kárí go by the supporters of his opponent. Here, the expression was aided by the body language that connotes 'go away', 'you have overstayed', 'enough is enough', 'you are not wanted any more'. It should be stressed here also that, interpretation of these new idioms are made possible with their various contexts of usage including the extra contextual use of the body language which also aids the understanding of the idiom. In another context, the same candidate was told to 'kárí kọmù' by his supporters during one of his political campaigns in 2003. 'Kárí kọ̣mmù means come and govern, people want you.

(ix) - Jẹun sápò

Literal meaning: Eat into the pocket

Idiomatic: Enrich your pocket

(x) - Jẹun sókè

Literal meaning: Eat into the upper stomach

Idiomatic: Move on/go on

Expressions such as the ones above are foregrounded because they are idiomatic. Their meanings cannot be derived from each of their lexical components. Expressions such as these are not allowed in standard Yorùbá because they are semantically deviant. These items are frequently used to describe fraudulent tendencies of some politicians. For instance, in 'Ọmọ Gómìnà' (Governor's Child), a film produced and directed by Áńtà Láníyan, a character called Oșùolálé uses the expression in a discussion with his friend Akínbọ to portray politicians as fraudulent and corrupt individuals when complaining about shortage of money in circulation thus:

Akinbọ̀: Oṣùọálé, ǹjẹ o rántí san owó ẹgbẹ tìrẹ fún akọ̀wé ẹgbẹ kí o tó kúrò nínú ìpàdé. 
Oșùọlalé: K' lò ń sọ nígboro ẹnu y̌ı̆? Níbo ni o ti fẹ́ kí n rówó? Àfi bí ẹni pé àwọn olóșèlú ti kó gbogbo owó ìlú nílẹ tán. Wọ́n kàn ń jẹun sápò ni.

Akínbọ: $\quad$ Oșùọlalé, did you remember to pay your own association money to the secretary before you left the meeting?

Oșùọlalé: What exactly are you saying? Where do you expect me to get money? It is like the politicians have packed all the money in circulation. They are just enriching their pockets.

The underlined expression, which literally means 'eat into the pocket,' can be interpreted as "our politicians are just enriching themselves with public funds". This interpretation is arrived at because of the political information expressed in the context which gives clue to the comprehension of the excerpt. In a similar vein, the expression ‘jẹun sókè' for "move/go on" can be used in different contexts. Let's consider the example below:

Òkè ni A.C.N wà nínú ìwé ìdibò yẹn,

Òkè ni kí ẹ jẹun sí

The A.C.N is located at the uppermost position

in the ballot paper, eat into the upper stomach.

The excerpt is credited to the incumbent governor of Lagos State, Babátúndé Rájí Fáșolá (BRF) during one of the political rallies of his party (Action Congress of Nigeria) held on the 5th of March 2011 at the Tàfáwà Bàléwà Square (TBS) Lagos State. The rally was covered by the Lagos Television (L.T.V) and TV Continental (TVC). The underlined expression is idiomatic and requires socio-political information, as reflected in the context such as the above for a meaningful interpretation. It is abnormal to eat into the upper stomach (jẹun sókè). Eat into the stomach (jẹun síkùn) is the normal way of saying it. However, in this context, the expression is embedded with the socio-political 
meaning of 'cast your vote for the A.C.N', whose logo and name appear in the upper part of the ballot paper. The Governor is trying to educate his supporters on where to cast their votes, that is, the position of the party logo on the ballot paper. This idiom elicits laughter. Consequently, the mammoth crowd who found joy, happiness and entertainment in the use of the expression 'òkè ni ki e jẹun si' (eat into the upper stomach) could not hide their feelings as Fáșolá himself was hailed and adored.

\section{Findings}

In this paper, we discovered that new Yoruba idioms and idiomatic expressions were found to be used to express certain socio-political issues in Nigeria, especially in some part of western Nigeria. These political issues were expressed in a special and unique ways in the following socio-political contexts: 'Eté' (name of a politician) for corruption/stealing; Ojúyọbọ́ (physical description of a politician) for under achiever; Yóó wọlé ẹẹken si (He would win once again) for deceit; Ó bọjẹe tì (It would never retrogress or go backward) for collective support; Oyin ni o (It is honey) for a successful tenure; Ajímọbi/Àjùmọ̣se (a politician's name) for collective responsibility; Nàijá (pidgin name for Nigeria) for affection/ disappointment and Kárí go/Kárí kọ̣mù (carry go/carry come) for continuity and discontinuity.

Nominalisation, pidginisation and dialect expressions were the strategies employed for the formation of new idioms in this paper. These strategies were used to express different political happenings contextualized in underachievement, sloganeering for support, deceit and acceptance/rejection for second term in office respectively.

New idioms and idiomatic expressions, used to express socio-political issues in Yorùbá routine communication, occurred in mediated and non-mediated contexts and were conveyed through nominalization, pidginisation, and dialect expressions. These idioms reflect dynamism and modernity-constrained stylistic choices in Yorùbá. 


\section{Conclusion}

New idioms and idiomatic expressions are quintessentially unique expressions, mostly used in a special and peculiar way when viewed from communicative and stylistic perspective. We therefore, conclude from the foregoing, especially the linguistic strategies involved in the formation of the new idioms and idiomatic expressions, that in spite of the globalisation, which imposes new global communicative challenges on the people, especially the politicians and their followers, the Yorùbá language has the mechanism to cope with such communicative exigencies. The evolution of the new idioms and idiomatic expressions thus becomes a coping strategy to meet the new challenges.

\section{References}

AKÀNmÚ, Dayo (2003) “Àșàdídá İgbàlódé àti Ìlò wọn fún Ìdàgbàsókè Èdè Yorùbá", Lánghbásà, 10, 4, March 2003, 42-53.

AwÓBùtúyì, Oladele (1992) “Lexical Expansion in Yorùbá: Techniques and Principles", Burbark, 2, 2, June 1992, 14-32.

BABALỌLÁ, Adeboye (1972) "The Growth of the Yorùbá Language: Problems encountered and Solutions Essayed", Paper presented to the Tenth West African Languages Congress, University of Ghana.

BÁMgBósÉ, A. (1975) "Relative Clauses and Nominalized Sentences in Yorùbá", in R. K. Herbert (ed.), Proceedings of the Sixth Conference on African Languages, Columbus, Ohio: Department of Linguistics, Ohio State University, 202-209.

CRYSTAL, David (1997) ${ }^{2}$ The Cambridge Encyclopedia of Language, Cambridge: Cambridge University Press

MUKArousky, Jan (1970) "Standard Language and Poetic Language", in D. C. Freeman (ed.), Linguistic and Literary Style, Massachusetts: Holt, Rinehart and Winston Inc., 40-59.

NiCHOLS, Johanna (1980) "Pidginisation and Foreigner Talk: Chinese pidgin Russian", in E. C. Traugott, R. Labrum \& S. Shepherd (eds.), Fourth International conference on historical linguistics, Amsterdam: Benjamins, 397-407. 
OLÁTÉJÚ, Adeshola (2005) "The Phenomenon of New idioms in Yoruba Literary and routine Communication", in Toyin Falola \& Ann Jenova (eds.), Yoruba Creativity, Fiction, Language, Life and Songs, Africa World Press, Inc., 273-287.

OWóLABÍ, Kola (1976) “Noun-noun Constructions in Yorùbá Language”, Ph.D. Thesis, Arts, University of Ibadan, İbàdàn.

RUWET, Nicolas (1973) An Introduction to Generative Grammar, Amsterdam: North-Holland.

SÀLÁmì, Yinusa Kehinde (2006) "Yorùbá Proverbs and Democratic Ethos", Proverbium, 6, 3, 303325.

YUSUF, Omolayo (2002) Understanding English Usage, Ibadan: Joyful Printing Press 